\title{
Isolation and 18S ribosomal DNA gene sequences of Marteilioides chungmuensis (Paramyxea), an ovarian parasite of the Pacific oyster Crassostrea gigas
}

\author{
Naoki Itoh ${ }^{1, *}$, Tadashi Oda ${ }^{2}$, Tomoyoshi Yoshinaga ${ }^{1}$, Kazuo Ogawa $^{1}$ \\ ${ }^{1}$ Laboratory of Fish Diseases, Department of Aquatic Bioscience, Graduate School of Agricultural and Life Sciences, \\ University of Tokyo, Yayoi 1-1-1, Bunkyo, Tokyo 113-8657, Japan \\ ${ }^{2}$ Fish Propagation Section, Fisheries Experiment Station, Okayama Prefecture, Ushimado, Okayama 701-4303, Japan
}

\begin{abstract}
To develop sensitive detection techniques with the aim of elucidating the life cycle of Marteilioides chungmuensis, an intracellular paramyxean infecting the ovary of the Pacific oyster Crassostrea gigas, we isolated the parasite at the sporont stage from infected oysters using a freezethaw procedure at $-20^{\circ} \mathrm{C}$ and differential centrifugations in discontinuous sucrose and Percoll gradients. DNA was extracted from the isolated sporonts, and a PCR amplicon of 18S small subunit ribosomal RNA gene DNA was partially sequenced. In situ hybridization using 3 parasite-specific probes designed from the obtained sequence successfully detected parasite cells in infected oysters, and confirmed that the sequenced DNA was derived from M. chungmuensis.
\end{abstract}

KEY WORDS: Marteilioides chungmuensis - Paramyxea · Isolation · Crassostrea gigas · Pacific oyster $\cdot 18 \mathrm{~S}$ ribosomal DNA gene sequence $\cdot$ In situ hybridization

Resale or republication not permitted without written consent of the publisher

\section{INTRODUCTION}

Species of the genus Marteilioides are parasites of oysters, and 3 species are currently known: Marteilioides chungmuensis from the ovocyte of the Pacific oyster Crassostrea gigas (Comps et al. 1986, Park \& Chun 1989, Imanaka et al. 2001, Itoh et al. 2002); $M$. branchialis from the gill of the Sydney rock oyster Saccostrea glomerata (= S. commercialis) (Anderson \& Lester 1992); and Marteilioides sp. from the ovocyte of the Sydney rock oyster (Hine \& Thorne 2000). M. chungmuensis poses a serious problem for oyster fisheries in Japan, because infected oysters display an abnormal appearance, resulting in the loss of marketability. In Korea, M. chungmuensis was first reported as an amoeba (Chun 1979), then identified as a new species in the genus Marteilioides by Comps et al. (1986). Although a parasite similar to M. chungmuensis had also been reported in Japan by several authors (Seki 1934, Matsusato et al. 1977, Imanaka et al. 2001), the parasite was not identified until this year, when
Itoh et al. (2002) confirmed it as the same parasite reported in Korea.

The sporulation stages of Marteilioides chungmuensis in the host cell have been studied by Park \& Chun (1989), Imanaka et al. (2001) and Itoh et al. (2002), and it has been postulated that spores in the ovocyte are released from the oyster ovary via the genital canal into the environment (Itoh et al. 2002). However, developmental stages other than the sporulation stages, such as vegetative and infective stages, have not yet been detected. This is because an adequately sensitive detection method has so far not been developed.

Recently, the ribosomal DNA genes (18S rDNA) of 2 related paramyxean pathogens, Marteilia refringens and M. sydneyi, were sequenced (Anderson et al. 1995, Berthe et al. 2000). Molecular techniques were then employed for the detection of both these pathogens (Le Roux et al. 1999, Kleeman \& Adlard 2000), the early developmental stages of M. sydneyi (Kleeman et al. 2002) and a possible alternative host of $M$. refringens (Audemard et al. 2002). Additionally, 
Berthe et al. (2000) postulated the phylogenetic position of $M$. refringens. However, diagnostic molecular techniques have not yet been developed for $M$. chungmuensis, as the presence of parasites in the host ova make isolation of the parasite difficult.

In the current study, we described an isolation method for this ovarian parasite, performed the partial sequence of the small subunit ribosomal gene and developed a molecular detection method using in situ hybridization.

\section{MATERIALS AND METHODS}

Infected oysters. For the isolation of the parasite, oysters infected with Marteilioides chungmuensis were collected at Ushimado, Okayama Prefecture, Japan, in November 2001, where M. chungmuensis is prevalent (Itoh et al. 2002). Each oyster was opened, and infection by the parasite was confirmed by gross and wet-mount slide observations. The infected ova were excised, then frozen at $-20^{\circ} \mathrm{C}$.

Isolation of parasite sporonts. Established isolation methods involving discontinuous gradients for other shellfish protozoan parasites, such as Bonamia ostreae (Mialhe et al. 1988), Marteilia refringens (Mialhe et al. 1985) and Mikrocytos mackini (Hervio et al. 1996), were not successful. We modified the usual isolation methods for the isolation of parasite sporonts. Frozen infected ova (weighing $27.3 \mathrm{~g}$ ) were thawed and homogenized with a glass homogenizer in filtered $(0.22 \mu \mathrm{m})$ seawater (FSW) supplemented with $1 \%$ Tween 80 (FSWT), and then sieved successively through 100, 60 and $20 \mu$ m nylon mesh to remove large tissue debris and fibrous materials. The homogenate was then sieved with $10 \mu \mathrm{m}$ nylon mesh to capture the sporonts (18 $\mu \mathrm{m}$ in diameter), while allowing host phagocyte cells to pass through the small nylon mesh. The mesh was washed with FSWT to suspend the sporonts, which were then collected in a petri dish.

The sporont suspension was dispensed into several $50 \mathrm{ml}$ plastic centrifuge tubes (Iwaki) and centrifuged $\left(10 \mathrm{~min}, 500 \times g, 4^{\circ} \mathrm{C}\right)$ to concentrate the parasite cells. The pellets were resuspended in $5 \mathrm{ml} \mathrm{FSWT}$, and layered on a discontinuous 30-40-50\% (w/w) sucrose gradient and centrifuged ( $25 \mathrm{~min}$, at $500 \times g, 4^{\circ} \mathrm{C}$ ). After centrifugation, the $40-50 \%$ interface was collected, washed twice in FSW with centrifugation (10 min, $500 \times g, 4^{\circ} \mathrm{C}$ ) and pelleted to eliminate sucrose.

The resulting pellets were resuspended in $1 \mathrm{ml} \mathrm{FSW}$ and layered on a $14 \mathrm{ml}$ Percoll (Pharmacia) 10-20\% discontinuous gradient (v/v: Percoll/FSW supplemented with $0.55 \mathrm{M} \mathrm{NaCl}$ ). After centrifugation (25 min, $500 \times g, 4^{\circ} \mathrm{C}$ ), the interface between 10 and $20 \%$ was collected, diluted in $15 \mathrm{ml}$ FSW and centrifuged $\left(10 \mathrm{~min}, 500 \times g, 4^{\circ} \mathrm{C}\right.$ ) to eliminate Percoll. The isolated sporonts were stained with the fluorescent dye DAPI (4',6-diamino-2-phenylindole) to confirm the presence of parasite cells and DNA (Wesche et al. 1999). The pellets were suspended in $1 \mathrm{ml}$ absolute ethanol and stored at $-20^{\circ} \mathrm{C}$ until DNA extraction took place.

DNA extraction. DNA was extracted from the suspension of the isolated sporonts $\left(1.18 \times 10^{7}\right.$ cells in $3 \mathrm{ml}$ ) using a QIAamp DNA Mini Kit (QIAGEN) following the manufacturer's tissue protocol, and the purified DNA was used for polymerase chain reaction (PCR) amplification.

PCR amplification. A part of 18S rDNA was amplified by PCR using 2 oligodeoxynucleotide primers designed in conserved regions in the rDNA, 530f (Vossbrinck et al. 1993), and PD-18S-R (Iwashita 2000) (Table 1). PCR reactions were carried out in $50 \mu \mathrm{l}$ volume according to the standard conditions of Takara Ex Taq (Takara Shuzo). The following temperature profile was employed using the GeneAmp PCR system 2400 (Perkin-Elmer): preheating at $94^{\circ} \mathrm{C}$ for $30 \mathrm{~min}, 35$ cycles of denaturation $\left(94^{\circ} \mathrm{C}, 30 \mathrm{~s}\right)$, annealing $\left(52^{\circ} \mathrm{C}, 3 \mathrm{~min}\right)$ and extension $\left(72^{\circ} \mathrm{C}, 3 \mathrm{~min}\right)$, and a further elongation step of $30 \mathrm{~min}$ at $72^{\circ} \mathrm{C}$.

Amplified products were analyzed electrophoretically on $1.5 \%$ agarose gel, as follows: After purification of the amplicons with a PCR amplicon purification kit (QIAGEN), the PCR products were digested with the restriction enzyme $S a c$ I for $2 \mathrm{~h}$ at $37^{\circ} \mathrm{C}$, and run out on a $1.5 \%$ agarose gel to confirm that the amplicon was not derived from host cells.

DNA sequencing. PCR amplicons were cloned into a pt-7 Blue T-vector system (Takara Shuzo). Recombinant plasmids were sequenced by means of the dideoxy chain termination method (Sanger et al. 1977) using a BigDye ${ }^{\mathrm{TM}}$ Terminator v3.0 Cycle Sequencing Ready Reaction Kit, and 310 DNA sequencer (Applied Biosystems), according to the manufacturer's instructions. Sequences were aligned with Genetic-

Table 1. Primers used for PCR reaction

\begin{tabular}{|llll|}
\hline Primer & Direction & Sequence & Tm \\
\hline 530f (Vossbrinck et al. 1993) & Forward & $5^{\prime}$-GTGCCAGC(C/A)GCCGCGG-3' & $54-$ \\
PD-18S-R (Iwashita 2000) & Reverse & $5^{\prime}$-GATCCTTCTGCAGGTTCACCT-3' & $55-$ \\
\hline
\end{tabular}


Mac/ATSQ 3.0 (Software Development), and compared for similarity with sequences lodged in GenBank using BLAST (Altschul et al. 1990).

In situ hybridization. To confirm that the obtained sequences were derived from the parasite, 3 oligonucleotide probes were designed for in situ hybridization studies (Table 2). The probes were labelled with digoxigenin using a Dig Oligonucleotide Tailing Kit (Boehringer Mannheim) according to Lee et al. (2000). Infected oysters were obtained in the Okayama Prefecture in October 2001 and February 2002, then fixed in $10 \%$ buffered formalin for at least $48 \mathrm{~h}$, and embedded in paraffin wax. Paraffin blocks were sectioned at $5 \mu \mathrm{m}$ thickness and placed on positive charged slides (Fisher Scientific). Hybridization reactions were performed with the MicroProbe Staining System (Fisher Scientific) using manual capillary actions modified from the manufacturer's instructions. Briefly, after baking in a $45^{\circ} \mathrm{C}$ oven, the sections were rapidly deparafinized, rehydrated with a Tris-HCl buffer, pH 7.4 (Universal Buffer, Research Genetics), and digested with pepsin (2.5 mg $\mathrm{ml}^{-1}$; Research Genetics) for $3 \mathrm{~min}$ at $105^{\circ} \mathrm{C}$. Probes diluted in formamidefree diluent were applied to the sections. The sections were heated to $105^{\circ} \mathrm{C}$ for $3 \mathrm{~min}$, cooled for approximately $1 \mathrm{~min}$ at room temperature, and allowed to hybridize at $45^{\circ} \mathrm{C}$ for $60 \mathrm{~min}$. The sections were then washed once with $2 \times \mathrm{SSC}$ (standard saline citrate; $0.3 \mathrm{M} \mathrm{NaCl}, 0.03 \mathrm{M}$ sodium citrate) at $45^{\circ} \mathrm{C}$ for $3 \mathrm{~min}$ and incubated with anti-DIG-AP antibody solution $(1: 500$ in Tris- $\mathrm{HCl}$ buffer, $\mathrm{pH}$ 7.5) for $20 \mathrm{~min}$ at $50^{\circ} \mathrm{C}$.

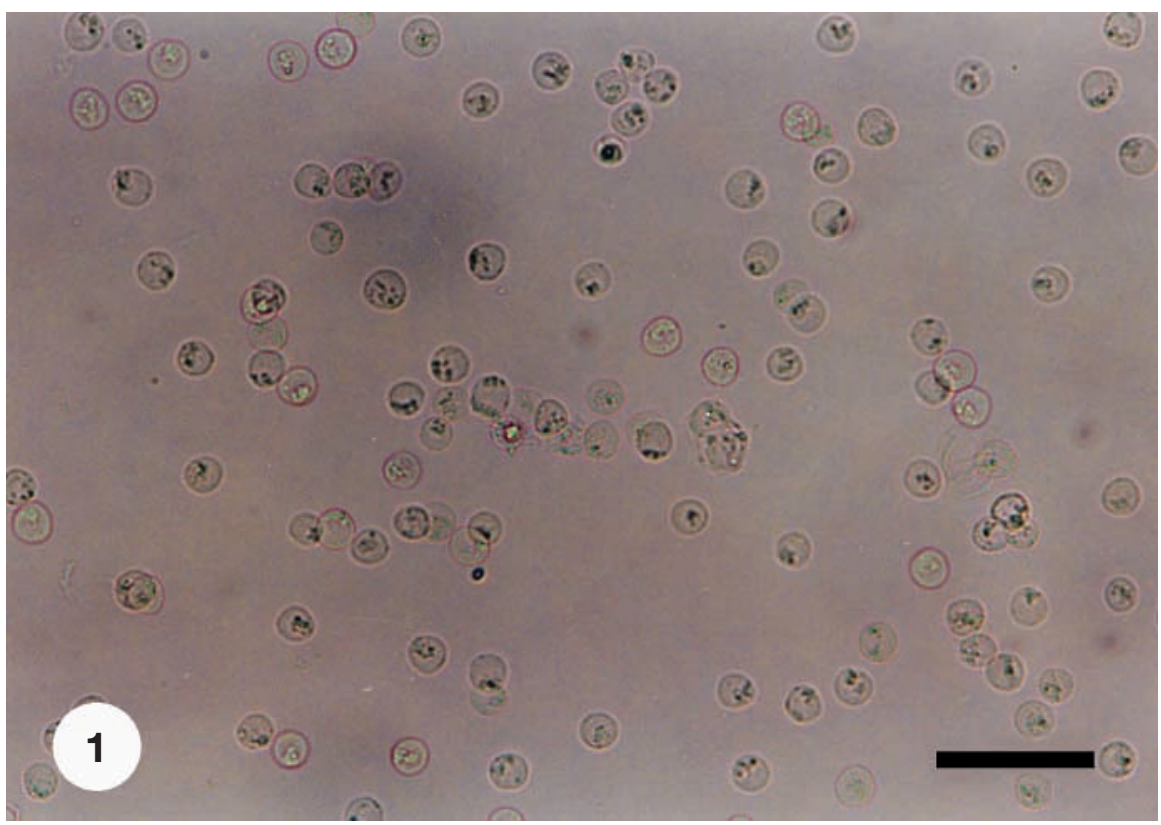

Fig. 1. Marteilioides chungmuensis. Isolated sporonts. Scale bar $=100 \mu \mathrm{m}$

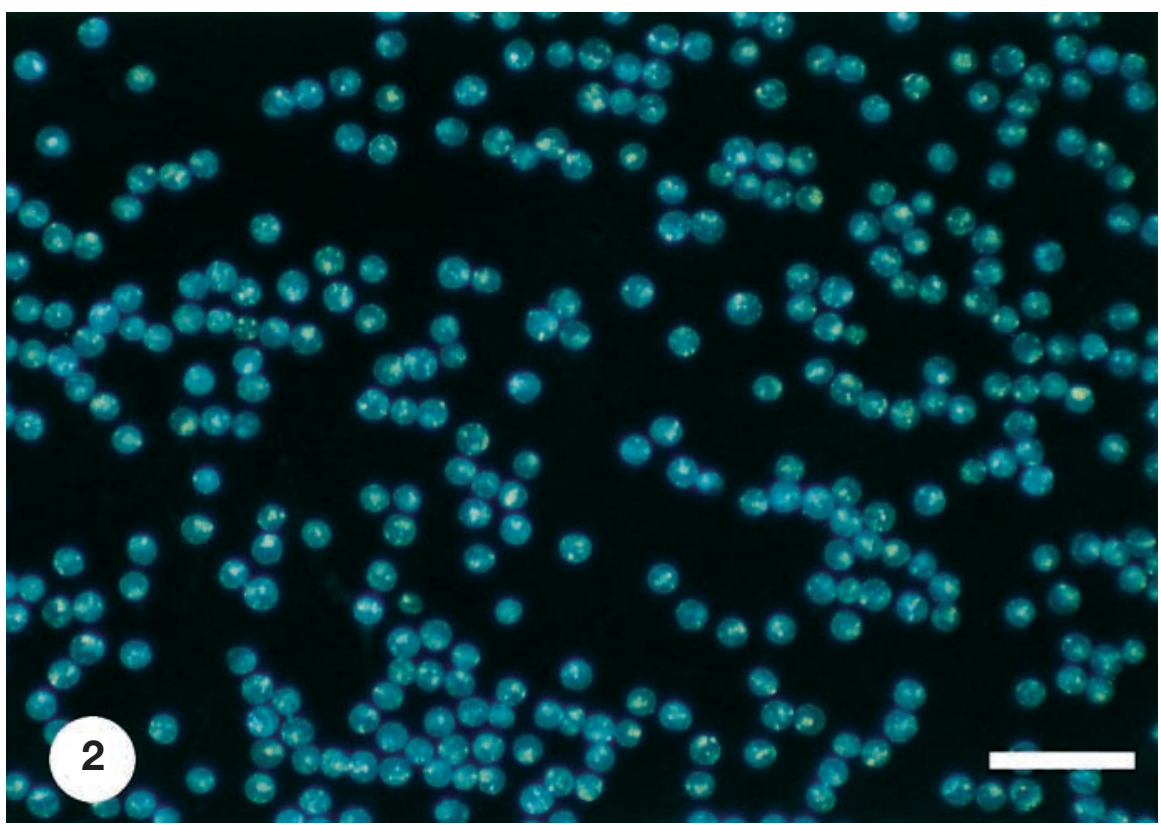

Fig. 2. Marteilioides chungmuensis. Isolated sporonts stained with DAPI (4', 6-diamino-2phenylindole), showing that they contain DNA. Scale bar $=80 \mu \mathrm{m}$

Table 2. Oligonucleotide probes used for the in situ hybridization

\begin{tabular}{|llll}
\hline Primer & Direction & Sequence & Tm \\
\hline MCSP-01 & Forward & $5^{\prime}$-AACGAGTCTCGTCTCGGAGCG-3' & $53-$ \\
MCSP-05 & Forward & $5^{\prime}$-GCACGAAAAGCCGGCCCAGTC-3' & $55_{-}^{\prime}$ \\
$6-\mathrm{R}$ & Reverse & $5^{\prime}$-AGGTATTCAGCCGGTGCTTCATCGGG-3' & $58-$ \\
\hline
\end{tabular}



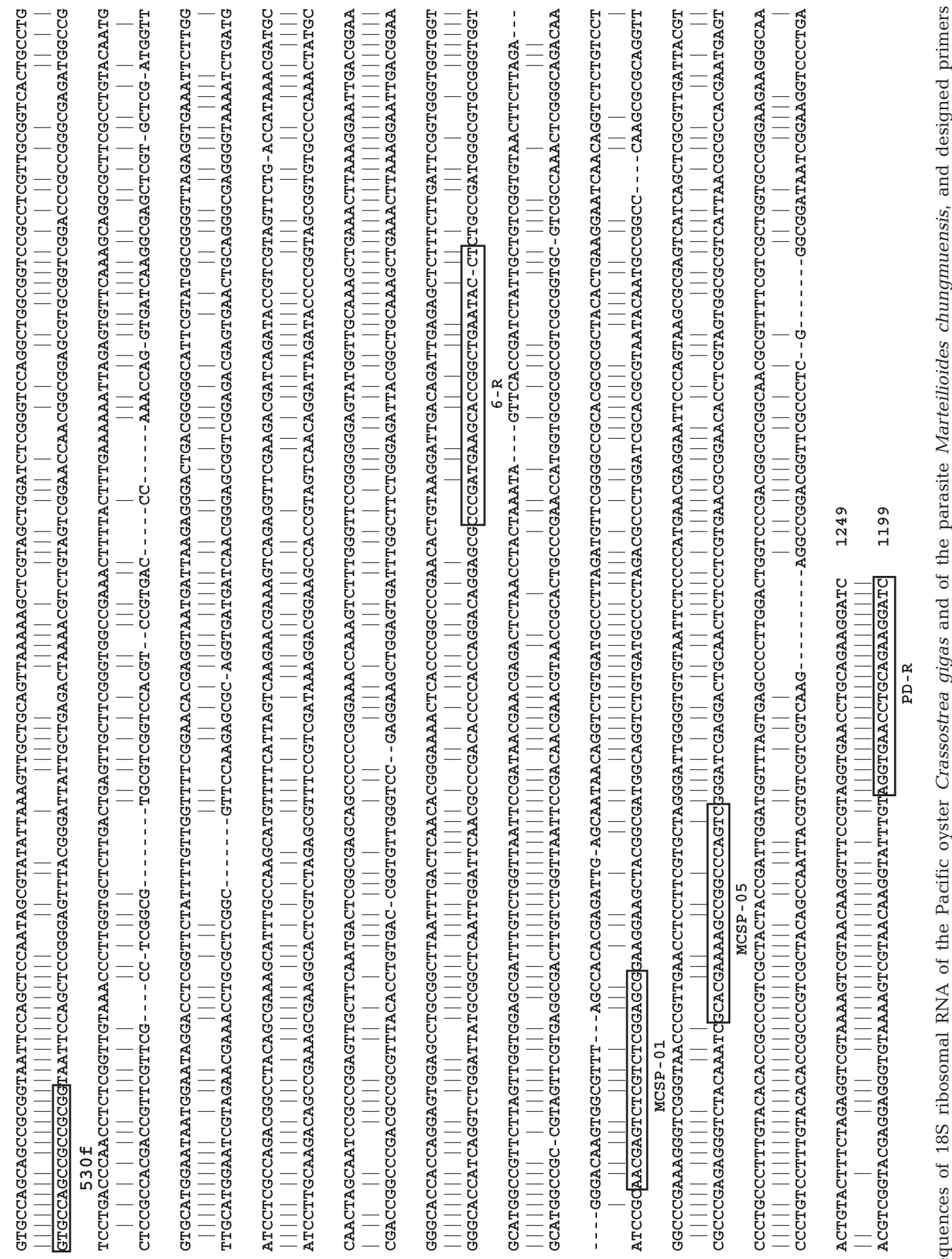

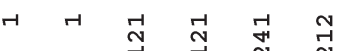

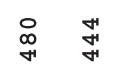

$$
\text { ㅇํㅇ ㅇำ }
$$

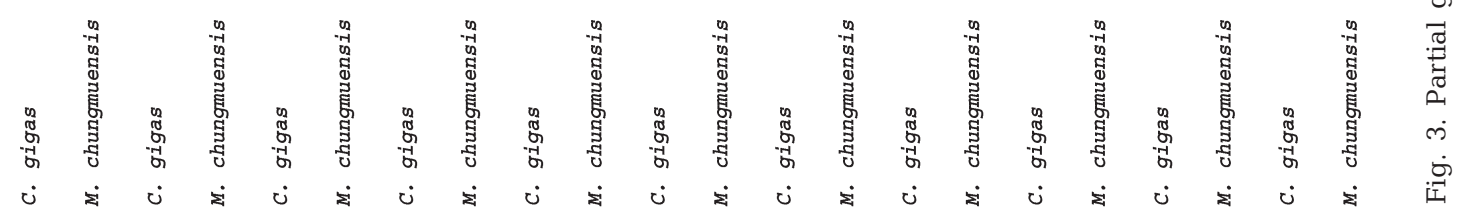




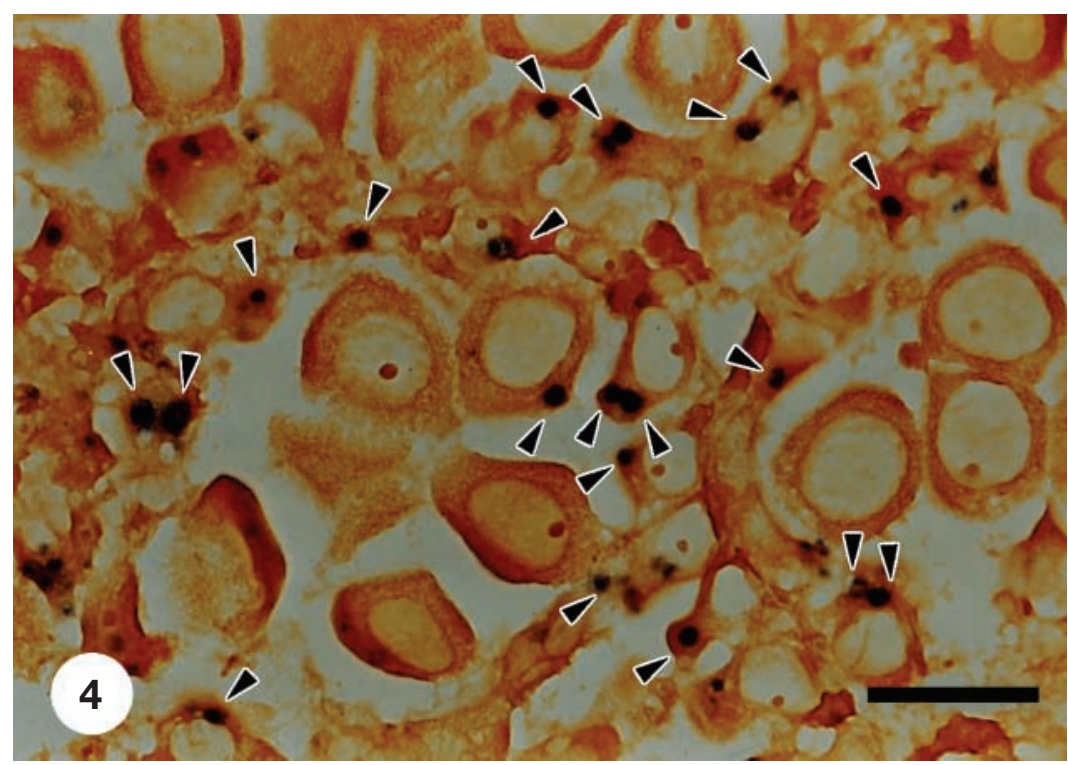

Fig. 4. Crassostrea gigas. In situ hybridization on the ovary of the Pacific oyster infected with Marteilioides chungmuensis sampled in February 2002. Note that immature sporogenic stages were presented in ova (arrowheads). Scale bar $=$ $50 \mu \mathrm{m}$

After washing 3 times in AP chromogen buffer $\mathrm{pH} 9.5$ (Research Genetics) at room temperature, the sections were incubated in nitroblue tetrazolium/bromochloroindolyl phosphate (NBT/BCIP, in Tris-HCl based buffer, $\mathrm{pH} 9.5$ ) for $30 \mathrm{~min}$ at $45^{\circ} \mathrm{C}$ to visualize the hybridized products. After in situ hybridization, the sections were counterstained with $0.05 \%$ Bismarck brown Y (Sigma).

\section{RESULTS}

The freeze-thaw procedure at $-20^{\circ} \mathrm{C}$ ruptured the oyster ova and primary cells of the parasite, resulting in free sporonts (secondary cells) in homogenates. Without this treatment, parasite cells were retained in host ova after the isolation procedure (data not shown).

In the isolation of Marteilioides chungmuensis in the sucrose gradients, the 40-50\% contained mainly sporonts; this interface also contained ova membranes and undigested diatom cells that oysters fed upon. In the discontinuous Percoll gradients, sporonts were isolated in the $10-20 \%$ interface, while oyster ova membranes were found in the $0-10 \%$ interface, and diatoms were under the $20 \%$ Percoll phase. Approximately $1 \times 10^{7}$ sporonts were isolated from $30 \mathrm{~g}$ infected gonad tissue (Fig. 1); no microorganisms other than sporonts were observed microscopically, and DAPI staining showed that the isolated sporonts contained DNA (Fig. 2).

When PCR was applied to the DNA extracted from the isolated sporonts using the universal primers 530f and PD-18S-R, an amplicon of $1200 \mathrm{bp}$ was obtained. When the PCR amplicons were digested with Sac I, 1000 and 200 bp fragments were obtained.

The DNA sequence of the parasite is shown in Fig. 3 and registered in GenBank (GenBank accession no. AB089819). Comparisons of this sequence with those in public databases using BLAST confirmed that it belongs to $18 \mathrm{~S}$ rDNA and bears the closest similarity to Marteilia refringens.

In the in situ hybridization, early sporulation and mature stages of Marteilioides chungmuensis showed positive reaction with oysters obtained in February 2002 (Fig. 4) and in October 2002 (Fig. 5), respectively, and no reactions were found on any host tissue (Figs. 4 \& 5). 


\section{DISCUSSION}

Recently, sensitive molecular detection methods such as PCR and in situ hybridization have been developed for the diagnosis and understanding of the life cycle of several species of bivalve parasites. So far, however, such molecular techniques have not been applied to Marteilioides chungmuensis, because the isolation of the parasite has not been achieved. Usual isolation protocols for other protozoan parasites of bivalves such as Bonamia ostreae (Mialhe et al. 1988), Marteilia refringens (Mialhe et al. 1985, Robledo et al. 1995) and Mikrocytos mackini (Hervio et al. 1996) were not applicable to the $M$. chungmuensis harboured in the host ovocyte. The isolation protocol developed in the present study made it possible to rupture oyster ovocytes with the freeze-thaw procedure at $-20^{\circ} \mathrm{C}$, and to collect sporonts effectively using nylon mesh filtration and centrifugation. It was demonstrated by DAPI that the isolated sporonts contained DNA, and they were used for DNA analysis. We failed to isolate parasite cells from oysters obtained from December 2001 to February 2002, when mature sporonts were absent in infected oysters. The best period for isolating parasite cells was from late summer to early winter (August to November 2002), when mature sporonts were frequently observed in infected oysters.

Our previous work (Authors' unpubl. data) on the 18S rDNA sequence of the Pacific oyster (GenBank accession no. AB064942) showed that the rDNA has a single recognition site by Sac I between the annealing site of the used primer 530f and PD-18S-R, resulting in 694 and 556 bp fragments. On the other hand, the digestion of the present PCR amplicon by Sac I generated 1000 and $200 \mathrm{bp}$, indicating that the amplicon was not derived from the host oyster. The sequence of the amplicon bore a close resemblance to the $18 \mathrm{~S}$ rDNA gene of Marteilia refringens (GenBank accession no. AJ250699). Moreover, the probes designed from the sequence showed a positive reaction to $M$. chungmunensis in the in situ hybridization. This demonstrates that the obtained sequence was the $18 \mathrm{~S}$ rDNA of the parasite.

Only parasite cells showed positive signals in the in situ hybridization, indicating that this technique detects the parasite in oysters effectively. Interestingly, Kleeman et al. (2002) found previously unknown stages of a related pathogen, Marteilia sydneyi, in the Sydney rock oyster, which led to the establishment of a hypothetical life cycle. So far, only sporogonic stages in host ova have been described for $M$. chungmuensis (Park \& Chun 1989, Imanaka et al. 2001, Itoh et al. 2002). We therefore expect that this newly applied technique will contribute to the discovery of previously undetected developmental stages of the parasite.
In the present study, once an isolation method for Marteilioides chungmuensis was established, its 18S rDNA was partially sequenced. This sequence will be helpful in the further development of molecular detection techniques such as PCR and in situ hybridization, which in turn will lead to the elucidation of the parasite's life cycle.

Acknowledgements. We thank the staff of the Fisheries Experiment Station, Okayama Prefecture, for supplying samples. We are grateful to Dr. Craig J. Hayward of the University of Queensland, who kindly reviewed the manuscript. We also acknowledge Mr. K. Okubo of the University of Tokyo for his technical advice on using the gene sequencer, and Ms. S. J. Lee and Mr. I. Fujiyama of the University of Tokyo for their assistance with in situ hybridization.

\section{LITERATURE CITED}

Altschul SF, Warren G, Miller W, Myers EW, Lipman DJ (1990) Basic local alignment search tool. J Mol Biol 215: 403-410

Anderson TJ, Lester RJG (1992) Sporulation of Marteilioides branchialis $\mathrm{n}$. sp. (Paramyxea) in the Sydney rock oyster, Saccostrea commercialis: an electron microscope study. J Protozool 39:502-508

Anderson TJ, Adlard RD, Lester RJG (1995) Molecular diagnosis of Marteilia sydneyi (Paramyxea) in Sydney rock oysters, Saccostrea commercialis (Angas). J Fish Dis 18: $507-510$

Audemard C, Le Roux F, Barnaud A, Collins C and 6 others (2002) Needle in a haystack: involvement of the copepod Paracartia grani in the life-cycle of the oyster pathogen Marteilia refringens. Parasitol 124:315-323

Berthe F, Le Roux F, Peyertaillade E, Peyeret P, Rodriguez D, Gout M, Vivares CP (2000) Phylogenetic analysis of the small subunit ribosomal RNA of Marteilia refringens validates the existence of phylum Paramyxea (Desportes \& Perkins, 1990). J Eukaryot Microbiol 47:288-293

Chun SK (1979) Amoeba infection in oyster (Crassostrea gigas). Bull Korean Fish Soc 12:281-285

Comps M, Park MS, Desportes I (1986) Etude ultrastructurale de Marteilioides chungmuensis n. g., n. sp. parasite des ovocytes de l'huitre Crassostrea gigas Th. Protistologica 22:279-285

Hervio D, Bower SM, Meyer GR (1996) Detection, isolation, and experimental transmission of Mikrocytos mackini, a microcell parasite of pacific oyster Crassostrea gigas (Thunberg). J Invertebr Pathol 67:72-79

Hine PM, Thorne T (2000) A survey of some parasites and diseases of several species of bivalve mollusc in northern Western Australia. Dis Aquat Org 40:67-78

Imanaka S, Itoh N, Ogawa K, Wakabayashi H (2001) Seasonal fluctuations in the occurrence of abnormal enlargement of the ovary of Pacific oyster Crassostrea gigas at Gokasho Bay, Mie, Japan. Fish Pathol 36:83-91

Itoh N, Oda T, Ogawa K, Wakabayashi H (2002) Identification and development of a paramyxean ovarian parasite in the Pacific oyster Crassostrea gigas (Thunberg). Fish Pathol 37:23-28

Iwashita M (2000) Phylogenetic study of the species of the sub-family Pseudodactylogyrinae Ogawa, 1986 (Monogenea:Pseudodactylogyridae). PhD thesis, University of Tokyo, Tokyo (in Japanese) 
Kleeman SN, Adlard RD (2000) Molecular detection of Marteilia sydneyi pathogen of Sydney rock oysters. Dis Aquat Org 40:137-146

Kleeman SN, Adlard RD, Lester RJG (2002) Detection of the initial infective stages of the protozoan parasite Marteilia sydneyi in Saccostrea glomerata and their development through to sporogenesis. Int J Parasitol 32:767-784

Le Roux F, Audenard C, Barnaud A, Berthe FCJ (1999) DNA probes as potential tools for the detection of Marteilia refringens. Mar Biotechnol 1:588-597

Lee SJ, Yokoyama H, Ogawa K, Wakabayashi H (2000) In situ hybridization for detection of the microsporidian parasite Glugea plecoglossi by using rainbow trout as an experimental infection model. Fish Pathol 35:79-84

Matsusato T, Hoshina T, Arakawa Y, Matsumura K (1977) Study of 'the abnormal egg mass' of the Pacific oyster, Crassostrea gigas (Thunberg). I. Bull Natl Res Hiroshima 8:9-25 (in Japanese)

Mialhe E, Bachere E, LeBec C, Grizel H (1985) Isolement et purification de Marteilia (Protozoa: Ascetospora) parasites de bivalves marins. CR Acad Sci III-VIE 301:137-142

Mialhe E, Bachere E, Chagot D, Grizel H (1988) Isolation and purification of the protozoan Bonamia ostreae (Pichot et al., 1980), a parasite affecting the flat oyster Ostrea edulis L. Aquaculture 71:293-299

Editorial responsibility: Albert Sparks, Seattle, Washington, USA
Park MS, Chun SK (1989) Study on Marteilioides chungmuensis Compe et al., 1986 parasite of the Pacific oyster, Crassostrea gigas Thunberg. J Fish Pathol 2:53-70

Robledo JAF, Mialhe E, Figueras A (1995) Purification of several phases of the parasite Marteilia (Protozoa: Ascetospora) from mussels (Mytilus galloprovinacialis). In: Stolen JS, Fletcher TC, Smith SA, Zelikoff JT, Kaatari SL, Anderson RS, Soderhall K, Weeks-Perkins BA (eds) Techniques in fish immunology, Vol 4: immunology and pathology of aquatic invertebrates. SOS Publication, Fair Haven, NJ, p 117-121

Sanger F, Nicklen S, Coulson AR (1977) DNA sequencing with chain terminating inhibitors. Proc Natl Acad Sci 74: 5463-5467

Seki H (1934) The abnormal development of oyster gonads in Hiroshima Bay. Bull Japan Sci Soc 9:93-99 (in Japanese)

Vossbrinck CR, Baker MD, Didier ES, Debrunner-Vossbrinck BA, Sahdduck JA (1993) Ribosomal DNA sequences of Encephalitozoon helleni and Encephalitozoon cuniculi: species identification and phylogenetic construction. J Eukaryot Microbiol 40:354-362

Wesche SJ, Adlard RD, Lester RJG (1999) Survival of spores of the oyster pathogen Marteilia sydneyi (Protozoa, Paramyxea) as assessed using fluorogenic dyes. Dis Aquat Org 36:221-226

Submitted: September 5, 2002; Accepted: December 15, 2002 Proofs received from author(s): February 24, 2003 